\title{
"BANG SAM" SEBAGAI MEDIA PENGELOLAAN BAHAN BAKU KERAJINAN HASIL SAMPAH BERBASIS MOBILE PADA BANK SAMPAH SEKARMELATI DI KABUPATEN KUDUS
}

\author{
Arsya Yoga Pratama \\ Sistem Informasi, Fakultas Teknik, Universitas Muria Kudus \\ Email: 201553011@std.umk.ac.id \\ Yusiana Rahma \\ Sistem Informasi, Fakultas Teknik, Universitas Muria Kudus \\ Email:201553008@std.umk.ac.id \\ Fajar Nugraha \\ Sistem Informasi, Fakultas Teknik, Universitas Muria Kudus \\ Email: fajar.nugraha@umk.ac.id
}

\begin{abstract}
ABSTRAK
Bank sampah sekarmelati yang teletak di kabupaten kudus merupakan salah satu bank sampah produktif yang menghasilkan produk olahan dari sampah non organic berupa tas, tempat tisu, dll. Pemasaran produk olahan dari bank sampah sekarmelati sudah mencapai luar jawa, akan tetapi memiliki kendala yaitu kekurangan bahan baku akibat dari pengelolaan bahan baku yang tidak optimal. Selain itu supply bahan baku sampah dari masyarakat sekitar bank sampah sekarmelati tidak mencukupi. Penyebabnya masyarakat kesulitan dalam menyetorkan sampah karena jarak jangkauan ke bank sampah sekarmelati dengan lokasi pemukiman yang jauh, ataupun belum mengetahui lokasi bank sampah sekarmelati. Sehingga pengembangan melalui implementasi teknologi informasi perlu dilakukan untuk menjamin kelancaaran produksi olahan sampah dapat terus berjalan melalui pengelolaan bahan baku (sampah). Berdasarkan permasalah tersebut perlu adanya (Bang Sam) sistem informasi media pengelolaan baku berbasis mobile dengan memanfaatkan teknologi GPS (Global Positioning System). Penelitian ini diharapkan dapat membantu mengatasi permasalahan pada bank sampah sekarmelati.
\end{abstract}

Kata kunci: sampah; bank sampah sekarmelati; pengelolaan bahan baku; bang sam; mobile.

\begin{abstract}
The junior garbage bank in the holy district is one of the productive waste banks that produces processed products from non-organic waste in the form of bags, tissues, etc. Marketing of processed products from garbage bank sekarmelati has reached outside Java, but has constraints that is the lack of raw materials resulting from the management of raw materials are not optimal. Besides, the garbage material suppliers from the society around the garbage bank of sekarmelati are not sufficient. The cause of the community difficulties in depositing waste because the distance to the garbage bank sekarmelati garbage with a remote residential location, or not yet know the location of garbage bins sekarmelati. So that development through the implementation of information technology needs to be done to ensure the productivity of waste processing can continue through the management of raw materials (garbage). Based on these problems need to be (Bang Sam) mobile standard information based media management system by utilizing GPS technology (Global Positioning System). This research is expected to help solve the problems in securely rubbish bank.
\end{abstract}

Keywords: garbage; sekarmelati garbage bank; raw material management; bang sam; mobile.

\section{PENDAHULUAN}

Sampah adalah masalah dalam masyarakat yang sangat sulit untuk diatasi. Menurut Kementerian Lingkungan Hidup tahun 2012 setiap harinya masyarakat di indonesia menghasilkan 490.000 ton per hari atau total 178.850 .000 ton sampah dalam waktu setahun. Tingginya volume sampah yang dihasilkan baik oleh industri maupun masyarakat merupakan permasalahan umum yang dijumpai pada seluruh kota saat ini. Disamping dipengaruhi oleh daya beli masyarakat, permasalahan tingginya volume sampah juga dipengaruhi oleh tingkat pertumbuhan penduduk[1]. Sesuai Peraturan Menteri Negara Lingkungan Hidup Republik Indonesia Nomor 13 tahun 2012 Pasal ayat 1 dan 2 menjelaskan bahwa kegiatan Reduse, Reuse, 
dan Recycle atau mengurangi sampah, guna ulang sampah dan daur ulang sampah yang selanjutnya di sebut kegiatan 3R.

Kegiatan 3R juga dapat diartikan sebagai penggunaan kembali sampah yang layak pakai untuk fungsi yang sama ataupun fungsisionalitas yang lain serta kegiatan pengelolaan sampah untuk diproduksi ulang menjadi produk baru. Salah satu bentuk kegiatan yang mendukung pelaksanaan 3R (Reduse, reuse, dan recycle) adalah berdirinya Bank Sampah. Bank Sampah adalah tempat pemilahan dan pengumpulan sampah yang dapat di daur ulang atau digunakan kembali sehingga dapat memiliki nilai ekonomi yang lebih tinggi dibandingkan dengan sebelumnya.

Bank sampah saat ini juga berfungsi sebagai usaha masyarakat untuk menjadikan sampah yang terbuang menjadi barang yang bernilai jual dan dapat dipergunakan kembali. Bank sampah, dapat bersifat usaha perseorangan (masyarakat) ataupun dikelola oleh pemerintah. Dengan permasalahan sampah di Indonesia yang semakin pelik, keberadaan bank sampah dapat menjadi solusi dalam mengatasi sampah dengan pengumpulan sampah dan pemanfaatan sampah. Di desa Mlati Norowito Kabupaten Kudus terdapat suatu bank sampah yaitu Bank Sampah Sekarmelati di wilayah Kabupaten Kudus. Bank Sampah Sekarmelati ini berperan aktif dalam pengolahan sampah khususnya sampah non organik. Bank Sampah Sekarmelati telah memproduksi olahan sampah non organik yang pemasarannya mencapai luar Jawa[2].

Dengan pasar produk yang telah terbuka, menuntut untuk memproduksi sebanyak-banyaknya barang olahan sampah, namun supply bahan baku dari penyetoran masyarakat tidak mencukupi. Penyebabnya masyarakat kesulitan dalam menyetorkan sampah karena jarak jangkauan ke Bank Sampah Sekarmelati dengan lokasi pemukiman yang jauh, ataupun belum mengetahui lokasi Bank Sampah untuk penyetoran sampah.

Saat ini Kelompok Bank Sampah Sekarmelati tidak memiliki media pengelolaan bahan baku oleh untuk melihat presentase bahan baku yang sudah didapatkan dan mengontrol produksi produk olahan sampah. Sedangkan dalam proses produksi barang, bahan baku seharusnya terdokumentasi untuk memperkirakan produksinya. Sehingga pengembangan melalui implementasi teknologi informasi perlu dilakukan untuk menjamin kelancaaran produksi produk olahan sampah dapat terus berjalan melalui pengelolaan bahan baku (sampah).

Berdasarkan permasalah tersebut perlu adanya (Bang Sam) sistem informasi media pengelolaan baku berbasis mobile dengan memanfaatkan teknologi GPS (Global Positioning System). Penelitian ini diharapkan dapat membantu mengatasi permasalahan pada bank sampah sekarmelati.

\section{METODE}

Pendekatan yang digunakan untuk pengembangan sistem dalam penelitian ini adalah prototype. Pendekatan prototype digunakan untuk mempercepat implementasi beberapa bagian dari sistem selama atau sebelum fase persyaratan. Desain prototipe, dengan cepat dievaluasi oleh pelanggan / pengguna dan hasil evaluasinya digunakan untuk memperbaiki perangkat lunak yang dikembangkan [3]. Penggunaan metode dalam perangkat lunak menggunakan Object Oriented Design (OOD) dan menggunakan alat desain Unified Modeling Language (UML). Penggunan pemodelan OOD dalam desain sistem akan menghasilkan risiko dalam mengembangkan sistem perangkat lunak untuk diimplementasikan [4].

Metode pelaksanaan yang dilakukan dalam meneliti kenadala yang terjadi pada bank sampah Sekarmelati adalah sebagai berikut.

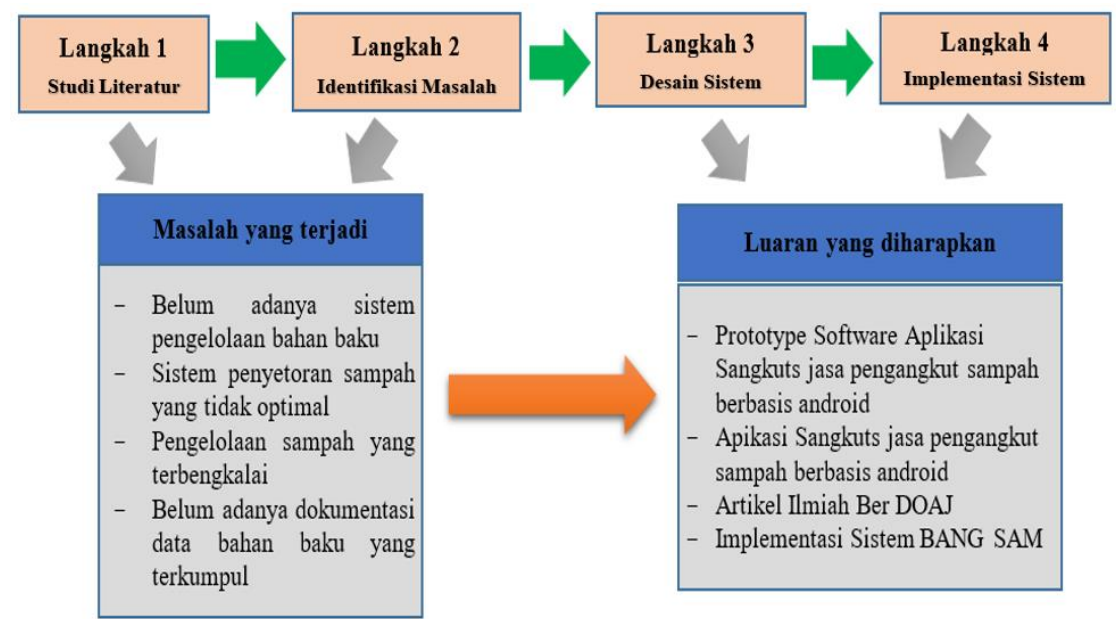

Gambar 1. Metode Pelaksanaan 
Dilihat dari gambar 1 diatas menunjukkan metode pelaksanaan dari kegiatan tersebut untuk mencapai target dengan langkah studi literatur, identifikasi, desain sistem, dan implementasi sistem. Dalam langkah pertama dan kedua dapat diperoleh permasalahan yang terjadi pada bank sampah yaitu belum adanya sistem pengelolaan bahan baku, sistem penyetoran sampah yang tidak optimal dari bank sampah Sekarmelati, pengelolaan sampah yang terbengkalai, dan belum adanya dokumentasi data bahan baku yang terkumpul.

Sehingga dari permasalahan tersebut akan dijadikan luaran dari permasalahan dengan prototype software aplikasi Bang Sam sebagai media pengelolaan bahan baku kerajinan hasil sampah, aplikasi Bang Sam sebagai media pengelolaan bahan baku kerajinan hasil sampah pada bank sampah Sekarmelati, artikel ilmiah ber DOAJ, dan Hak Cipta atas aplikasi yang dibangun. Luaran tersebut akan dilakukan pada langkah 3 dan 4 yakni desain sistem dan implementasi sistem Bang Sam.

\subsection{Study Literatur}

Dalam langkah study literatur ini, melakukan pengamatan atau observasi dengan mengamati proses terjadinya pengelolaan sampah pada Bank Sampah Sekarmelati dan mencari referensi teknologi untuk mengetahui cara mengimplementasikan sebuah data dengan memanfaatkan teknologi basis data dan teknologi GPS dalam smartphone Android untuk membuat aplikasi agar dapat lebih valid dalam menyajikan informasi bagi penggunanya.

Melakukan wawancara kepada pihak pengelola bank sampah Sekarmelati mengenai apa saja kendala yang dihadapi dari proses produksi kerajinan hasil sampah tersebut. Dengan begitu kami mendapat datadata yang akurat mengenali permasalahan yang ada disana untuk dijadikan bahan objek kegiatan yang dapat menjadi solusi permasalahan bank sampah Sekarmelati tersebut.

\subsection{Identifikasi Masalah}

Analisis masalah yang terjadi adalah bank sampah Sekarmelati kesulitan dalam melakukan pengelolaan bahan baku sehingga seringnya kekurangan bahan baku untuk produksi kerajinan hasil sampah pada pemesanan berikutnya. Terlebih lagi, selama ini sumber dari diperolehnya bahan baku adalah dari masyarakat, namun sulitnya mencari masyarakat yang menyetorkan sampah secara rutin dikarenakan kesibukan masing-masing masyarakat sehingga perlu dilakukannya suatu sistem untuk penjemputan sampah dari masyarakat sehingga mempermudah masyarakat dalam penyetoran sampah dengan memanfaatkan teknologi. Adapun sebagai data utama dalam pembuatan sistem yang diperlukan adalah:

a. Data Masyarakat sesuai nomor telepon

b. Data Sampah

c. Data Produk Olahan Sampah

d. Data Lokasi Penjemputan Sampah

\subsection{Desain Sistem}

Dalam langkah ini kita melakukan penerapan teknologi yang sesuai dengan permasalahan yang terjadi pada Bank Sampah Sekarmelati di desa Mlati Norowito. Dalam penerapannya kami membuat sebuah sistem baru untuk Bank Sampah Sekarmelati dengan mengintegrasikan teknologi basis data dan teknologi GPS dalam smartphone Android namun dapat dimanfaatkan sesuai kondisi dan kebutuhan dari Bank Sampah tersebut.

\subsection{Implementasi Sistem}

Pada tahap ini merupakan tahap yang penting karena sistem akan di ujicoba apakah sistem berjalan sesuai kebutuhan yang diperlukan atau tidak. Pada tahap ini berupa hasil yaitu prototype atau gambaran aplikasi. 


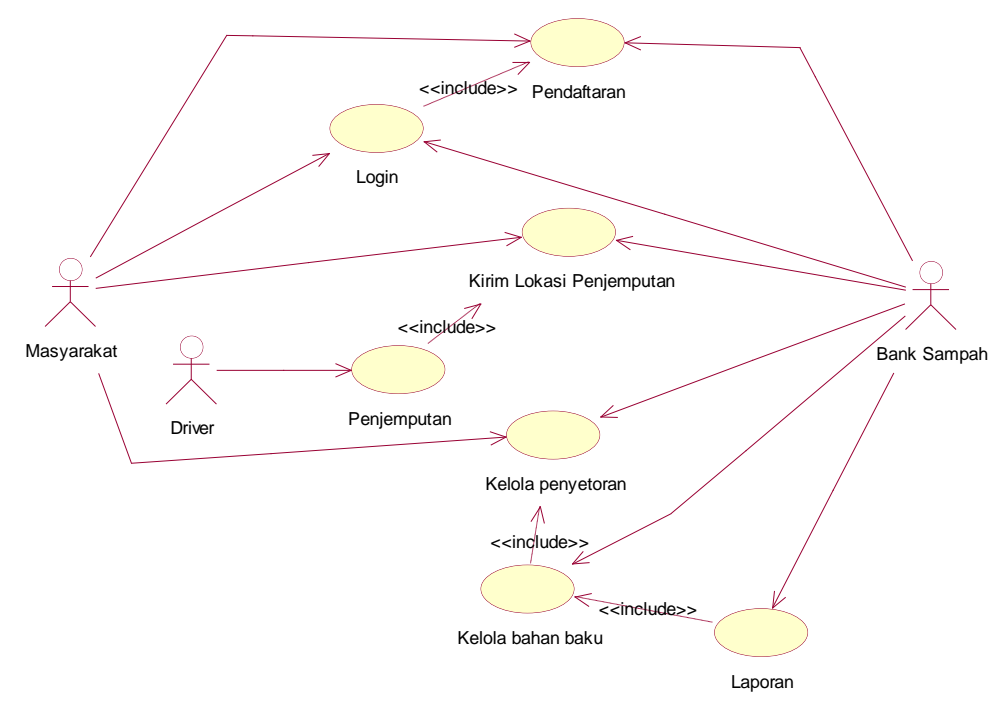

Gambar 2. Sistem Usecase Aplikasi Bang Sam

Dapat dilihat dari gambar 2 diatas merupakan system usecase dari apikasi Bang Sam yang dibangun. Secara garis besar, analisis sistem ini digambarkan dalam use case diagram. Use case ini merupakan gambaran keseluruhan aktifitas dan juga memberikan spesifikasi fungsi - fungsi yang ditawarkan oleh sistem dari perspektif user [7].

Dari sistem usecase tersebut dapat menunjukkan bahwa masyarakat dapat mengoperasikan aplikasi dengan mendaftar kemudian login sistem. Jika ingin menyetorkan sampah, maka masyarakat harus mengirm lokasi penjemputan terlebih dahulu kemudian driver akan menjemput sampah sesuai dengan pengiriman lokasi. Driver sendiri dapat menginputkan jumlah setoran yang diperoleh oleh masyarakat kemudian bank sampah akan mengelola hasil poin yang diperoleh masyarakat.

\section{HASIL DAN PEMBAHASAN}

Mobile adalah kata sifat yang berarti dapat bergerak atau dapat digerakkan dengan bebas dan mudah. Namun mobile dapat pula diartikan sebuah benda yang berteknologi tinggi dan dapat bergerak tanpa menggunakan kabel. Contohnya seperti smartphone, PDA, dan tablet. Mobile juga bisa diartikan kendaraan bermotor yang dapat bergerak. Mobile bersifat bebas seperti air dan dapat mengalir kemanapun. Mobile dapat berubah dan diubah dengan mudah. Jadi ada gambaran awal tentang mobile. Pengertian yang dibahas disini memang umum tidak sebatas smartphone atau handphone. Mobile bisa saja sebuah program yang dapat menjangkau seluruh tempat bisa diakses dengan mudah dan dapat diganti kapan saja tanpa kesulitan[5]. Disisi lain penjelasan tentang GPS (Global Positioning System) adalah Sistem ini didesain untuk memberikan posisi dan kecepatan tiga dimensi serta informasi mengenai waktu. sistem satelit navigasi dan penentuan posisi yang dimiliki dan dikelola oleh Amerika Serikat. [6]. 


\subsection{Sistem yang Dibangun}

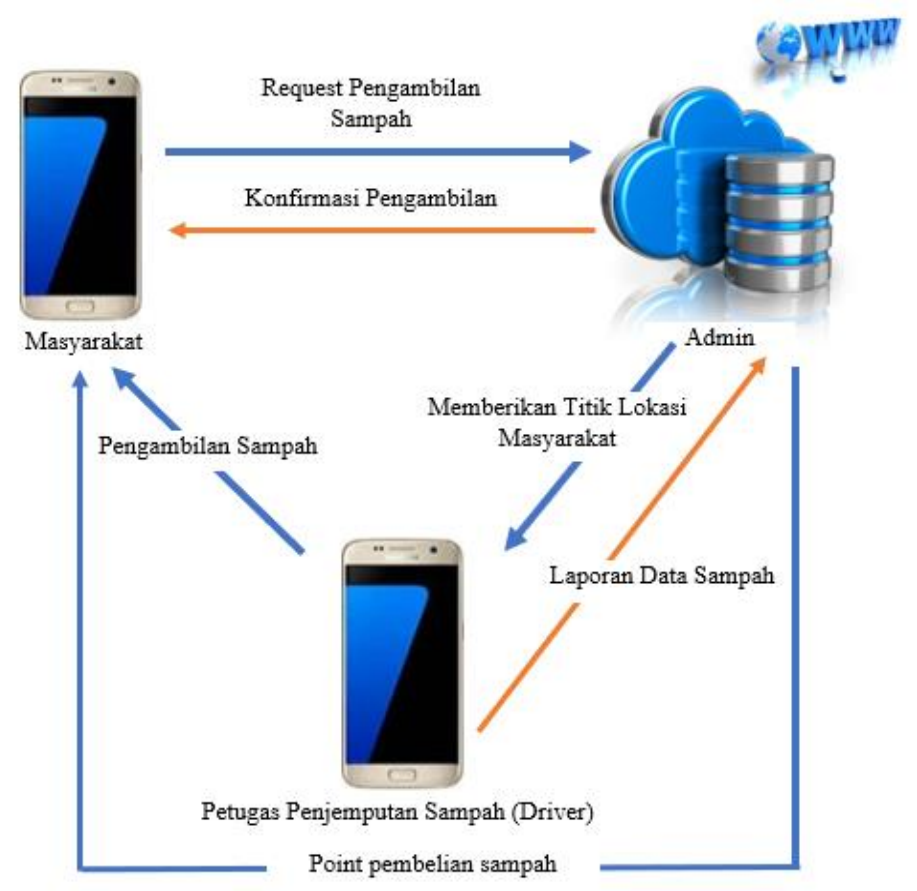

Gambar 3. Pengembangan Sistem

Pada gambar 4 diatas menunjukkan tentang pengembangan sistem pada apliaksi Bang Sam. Sistem kerja yang akan dibuat sebagai penerapan media pengeloaan bahan baku di Bank Sampah Sekarmelati. masyarakat melakukan request penjemputan sampah untuk disetorkan kepada Bank Sampah Sekarmelati. Setelahnya admin mengkonfirmasi request penjemputan sampah tersebut, sistem selanjutkan akan menginformasikan kepada petugas penjemputan sampah (driver) untuk melakukan penjemputan sampah pada lokasi yang sudah dikirim oleh masyarakat. Setelah melakukan penjemputan seluruh sampah akan dikumpulkan dan akan dilaporkan kepada admin.

Admin sendiri memiliki tugas untuk mendata seluruh penyetoran sampah perharinya, mendata masyarakat yang sudah menyetorkan untuk keperluan pembayaran hasil sampah yang telah disetorkan, serta merekap seluruh produksi sampah yang sudah diolah. Dari data admin inilah user masyarakat nanti akan terlihat point yang diperoleh saat penyetoran sampah tersebut sehingga nanti dapat ditukarkan dengan sejumpal uang kepada bank sampah sesuai dengan harga sampah yang sudah disetorkan.

\subsection{Prototype System}

Prototype adalah gambaran konsep aplikasi yang akan dibangun untuk dapat menjadi tujuan atau target aplikasi yang diinginkan sehingga pembuat dapat mudah dalam pembuatannya. Sistem adalah sekelompok unsur yang erat hubungannya satu dengan yang lain berfungsi bersama-sama untuk mencapai tujuan tertentu[7].

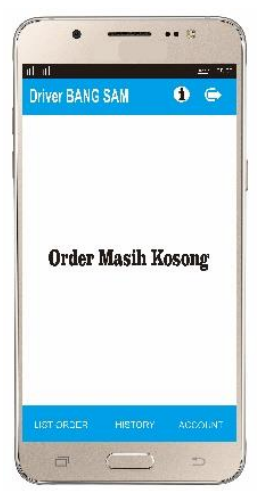

Gambar 4. Desain Interface Driver Bangsam 
Dilihat pada Gambar 5 Desain tampilan petugas penjemputan sampah terdapat beberapa menu seperti List Order, History, dan Account. List Order berfungsi untuk melihat order penjemputan sampah. History berfungsi melihat history penjemputan yang sudah diambil. Account berfungsi untuk melihat data diri driver.

Penggunaan memanfaatkan teknologi GPS (Global Positioning System) sangat berguna saat penjemputan setoran pada aplikasi ini. Driver sendiri dapat melihat jelas letak lokasi penjemputan yang sudah diisikan oleh masyarakat yang ingin menyetorkan sampah.

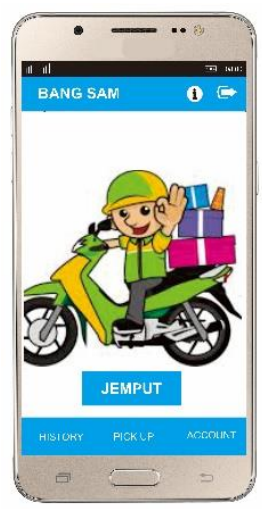

\section{Gambar 5. Desain Interface User}

Dilihat pada Gambar 6 Desain tampilan aplikasi masyarakat terdapat beberapa menu seperti History, Pick Up, dan Account. History berfungsi untuk melihat riwayat penyetoran sampah kepada bank sampah sekarmelati. Pick Up berfungsi untuk melakukan request penjemputan sampah serta terdapat list harga sampah apa saja yang dapat dijual. Account berfungsi untuk melihat dataa diri masyarakat.

\subsection{Aplikasi Bang Sam}

Definisi dari Android adalah sebuah sistem operasi yang berbasis Linux yang mencakup sistem operasi, middleware, dan aplikasi[8]. Berikut adalah implementasi aplikasi dari Bang Sam yang sudah dibangun untuk membantu permasalahan bank sampah Sekarmelati.

Perkembangan teknologi juga menyentuh aspek kepedulian terhadap lingkungan dengan adanya teknologi yang dapat menjadikan solusi dalam menangani masalah pengelolaan sampah[9].

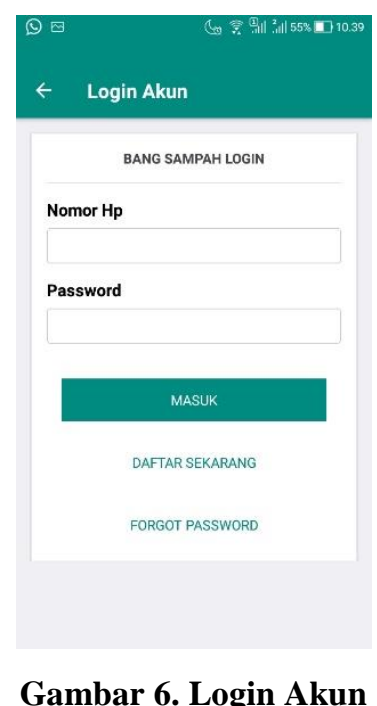

Dilihat pada gambar 7 adalah menu login menampilkan inputan nomer telepon dan password, jika belum memiliki akun aplikasi dapat mendaftar dengan klik menu daftar sekarang 


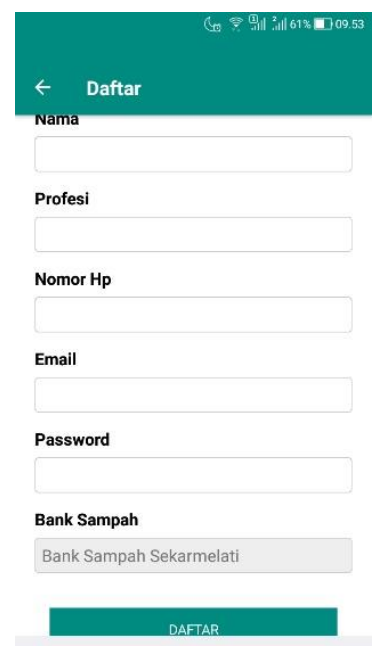

\section{Gambar 7. Menu Daftar}

Dapat dilihat dari gambar 8 menunjukkan inputan isian dari biodata user yang mendaftar pada aplikasi Bang Sam. Inputan berupa nama pengguna, profesi pengguna, nomor telepon pengguna, email dari pengguna, password akun, serta bank sampah yang dipilih untuk menjadi langganan setoran.

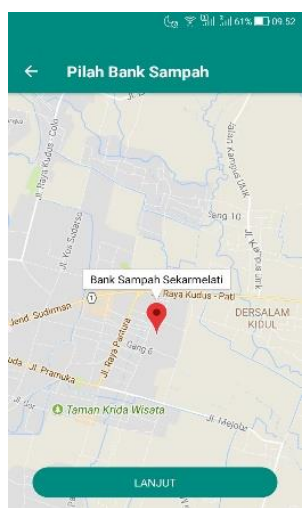

\section{Gambar 8. Menu Registrasi Bank Sampah}

Dilihat dari gambar 9 menunjukkan inputan pendaftaran dengan memilih bank sampah yang ingin dijemput untuk menyetor sampah kepada bank sampah Sekarmelati.

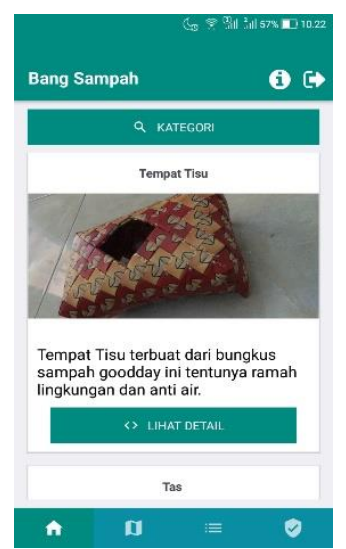

Gambar 9. Menu Produk

Dapat dilihat dari gambar 10 menunjukkan fitur kategori produk yang kategori produk kerjainan hasil sampah yang ada di bank sampah Sekarmelati. 


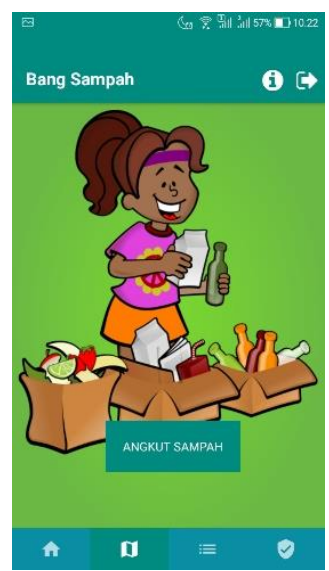

Gambar 10. Menu Home

Dilihat dari gambar 11 menunjukkan fitur dari aplikasi Bang Sam dengan memilih angkut sampah maka user dapat menyetorkan sampah pada bank sampah Sekarmelati dengan mengirimkan lokasi penjemputan.

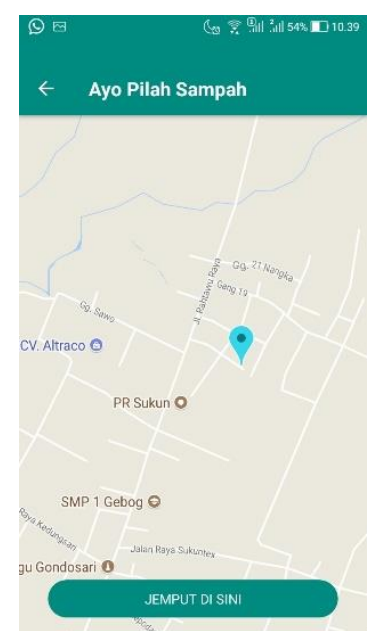

\section{Gambar 11. Menu Kirim Lokasi}

Dilihat dari gambar 12 menunjukkan fitur kirim lokasi untuk user yang ingin menyetorkan sampahnya kepada bank sampah Sekarmelati. Didukung dengan teknologi GPS (Global Positioning System). GPS (Global Positioning System) merupakan sebuah sistem satelit navigasi dan penentuan posisi dengan menggunakan satelit. GPS dapat memberikan informasi tentang posisi, kecepatan, dan waktu secara cepat, akurat, murah, dimana saja di bumi ini pada setiap saat tanpa tergantung cuaca. Pada dasarnya GPS terdiri atas tiga segmen utama [10]. 


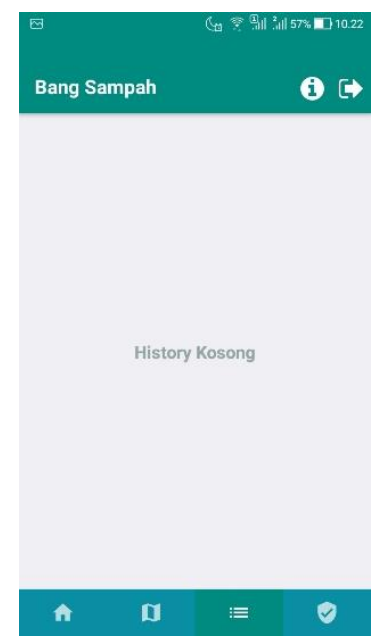

Gambar 12. Menu Histori

Dilihat dari gambar 13 diatas menunjukkan gambar aplikasi history dari penyetoran sampah oleh masyarakat. Jika belum melakukan penyetoran maka histori akan kosong.

\section{KESIMPULAN}

Dengan adanya penelitian tersebut permasalahan yang ada di bank sampah terutama bank sampah yang menjadi objek penelitian yakni bank sampah Sekarmelati dapat teratasi dengan memanfaatkan teknologi yang sudah berkembang saat ini. Kemudian adanya penelitian seperti ini dapat bermanfaat untuk bank sampah. Sehingga bank sampah dapat secara optimal memproduksi oalahan sampah dengan baik dan maksimal sekaligus dalam jangka panjangnya dapat mengurangi jumlah sampah.

\section{UCAPAN TERIMA KASIH}

Terima kasih kepada Kementerian Riset, Teknologi, dan Pendidikan Tinggi Republik Indonesia yang telah membiayai penelitian ini melalui program kreativitas mahasiswa bidang karsa penerapan teknologi.

Pihak Universitas Muria Kudus yang senantiasa memberikan dukungan dalam proses penelitian dengan cara memberikan motivasi-motivasi agar tim peneliti dapat melakukan penelitian secara maksimal dan mendapatkan hasil yang bagus pula.

Bank Sampah Sekarmelati Kudus yang telah bersedia menjadi objek penelitian dengan selalu menerima secara kooperatif dalam setiap kegiatan yang diselenggarakan dan menerima kedatangan peneliti untuk meneliti permasalahan yang ada di bank sampah tersebut.

\section{DAFTAR PUSTAKA}

[1] I. Surjandari, A. Hidayatno, and A. Supriatna, "Model Dinamis Pengelolaan Sampah Untuk Mengurangi Beban Penumpukan,” J. Tek. Ind., vol. 11, no. 2, p. PP. 134 - 147, 2009.

[2] Indarwati, "Hubungan antara Corporate Social Responsibility 'Surabaya Green \& Clean 2006," Surabaya.

[3] R. M Shalahuddin, A.S, Pembelajaran Rekayasa Perangkat Lunak (Terstruktur dan Berorientasi Objek). Bandung: Informatika, 2011.

[4] G. Booch, R. a. Maksimchuk, M. W. Engle, B. J. Young, J. Conallen, and K. a. Houston, Object-Oriented Analysis and Design with Applications, vol. 1, no. 11. 2007.

[5] H. Abidin, Penentuan Posisi dengan GPS dan Aplikasinya, no. PT. Pradnya Pramita. 2007.

[6] A. A. Budiawan, Tiyo and Santoso, Imam and Zahra, "Mobile Tracking GPS (Global Positioning System) melalui media SMS (Short Message Service)," 2011.

[7] A. Sinsuw and X. Najoan, "Prototipe Aplikasi Sistem Informasi Akademik Pada Perangkat Android," E-journal Tek. Elektro dan Komput., pp. 1-10, 2013. 
[8] R. F. Antasari and Kusrini, "Perancangan Aplikasi Mobile Bengkelku Sebagai Informasi Alamat Bengkel Resmi Sepeda Motor Di Kota Yogyakarta Menggunakan Gps Berbasis Android,” vol. 13, no. 4, pp. 38-42, 2012.

[9] S. Figure, "Aplikasi Smart Trash Can dalam mengatasi persoalan sampah secara mobile berbasis android," UIN alauddin, vol. 2, no. c, pp. 1-4, 2017.

[10] N. Safaat H, Android Pemrograman Aplikasi Mobile Smartphone dan Tablet PC berbasis Android. Bandung: Informatika, 2011. 